\title{
Testicular and epididymal histomorphometric assessment in F1 male Wistar rats after gestational Ricinus communis oil exposure
}

\author{
SALAMI, S. A. ${ }^{*}$, OMIRINDE, J. O. ${ }^{2}$, BALOGUN, M. E. ${ }^{3}$ and RAJI, Y. ${ }^{4}$ \\ ${ }^{1}$ Department of Physiology, Lagos State University College of Medicine - LASUCOM, P.M.B. 21266, Ikeja, Lagos, Nigeria \\ ${ }^{2}$ Department of Veterinary Anatomy, University of Jos, P.M.B 2084 Jos, Plateau State, Nigeria, Post code: 930001 \\ ${ }^{3}$ Department of Physiology, College of Health Sciences, Ebonyi State University, Abakaliki, Ebonyi State, Nigeria \\ ${ }^{4}$ Department of Physiology, College of Medicine, University of Ibadan, Ibadan Oyo State, Nigeria \\ *E-mail: piety1424@yahoo.com
}

\begin{abstract}
Introduction: Fetal programming hypothesis presupposes that stimulus or insult acting during critical periods of uterine growth and development do alter tissue structure and function. In the present study changes in histomorphometric integrity of the testes and epididymis in adult Fl male rats maternally exposed to Ricinus communis oil ( $\mathrm{RCO}$ ) at different gestation periods were assessed. Materials and Methods: Therapeutic dose of RCO $950 \mathrm{mg} / \mathrm{kg} \mathrm{BW}$ was administered to pregnant Wistar rats at gestation days GD 1-7, 7-14, 14-21 and 1-21 respectively. Testes and epididymis of adult male Fl offspring were then harvested for Histomorphometry assessment under Light microscope. Seminiferous tubular diameter (STD), seminiferous luminal diameter (SLD) and Seminiferous epithelial height $(\mathrm{EH})$ of both peripheral and central seminiferous tubules were measured in the testes. Epididymal tubular diameter (ETD), epididymal luminal diameter (ELD) and epididymal epithelial height $(\mathrm{EEH})$ were measured in epididymis. Results: Results were expressed as the mean \pm SEM and significance taken at $\mathrm{p}<0.05$. STD significantly $(\mathrm{p}<0.001)$ increased in Fl males from GD1 -7 , 7-14, 14-21 relative to control group. SEH significantly $(\mathrm{p}<0.001)$ decreased in Fl males from GD1-7,7-14 and 1-21. SLD increased significantly $(\mathrm{p}<0.001)$ in Flmales from GD 1-7, 7-14, 14-21 and 1-21. ETD significantly $(\mathrm{p}<0.01)$ increased in F1 males from GDl-7, 7-14, 14-21. EEH significantly $(\mathrm{p}<0.001)$ increased in F1 males from GD1-7 and GD7-14. ELD however increased significantly $(\mathrm{p}<0.001)$ only in Fl males from GD1-7. Conclusion: Maternal RCO exposure at different gestation periods impaired negatively histomorphometry of the testis and epididymis in male offspring.
\end{abstract}

Keywords: Ricinus communis oil, testes, epididymis, Flmales, histomorphometry.

\section{Introduction}

This is a follow-up to our previous study on generational reproductive effects of RCO. Fetal programming hypothesis presupposes that stimulus or insult acting during critical periods of uterine growth and development do alter tissue structure and function (MCMILLEN and ROBINSON, 2005). Increase in cases of reproductive disorders has highlighted concerns regarding consequences of intrauterine impact of endocrine disrupting chemicals on reproductive health (SAVABIEASFAHANI, KANNAN, ASTAPOVA et al., 2006). RCO has been reported to possess/used as laxative, labour inducing and estrogenic properties (STEINGRUB, LOPEZ, TERES et al., 1988; OKWUASABA, OSUNKWO, EKWENCHI et al., 1991; GARRY, FIGUEROA, GUILLAUME et al., 2000; COSMETIC..., 2007; BOEL, LEE, RIJKEN et al., 2010). We have earlier reported that Oral RCO exposure during pregnancy impaired hormonal, biochemical and histopathology of reproductive organs in Wistar rats (SALAMI and RAJI, 2014). This was followed by our study exploring the generational reproductive consequences of gestational exposure to RCO in offspring. In Fl males, alterations in androgen mediated reproductive endpoints were reported (SALAMI and RAJI, 2015). In addition sperm parameters and histopathology of the testes and epididymis were also impaired with severity depending on gestational period of exposure. The present study sought to dig further histological consequences of these findings using histomophometry. From the study of literature attempts at evaluating the reproductive toxicity effects of RCO have not explored adequately the field of histomorphometry in assessing the deleterious effects of RCO. This study therefore sought to assess changes in histomorphometric integrity of the testes and epididymis in adult Fl male rats maternally exposed to $\mathrm{RCO}$ at different gestation periods.

\section{Materials and Methods}

\subsection{Experimental design and treatment}

This study was conducted in accordance with guidelines for the care and use of laboratory animals and was approved by the Institutional Animal Care and Use Committee. Animals were kept in mass air-displacement room with a 12-h light-dark cycle at $18-26{ }^{\circ} \mathrm{C}$ and relative humidity of $30-70 \%$. Animals had access ad libitum to water and rodent chow (Ladokun Feeds Limited Ibadan). Nulliparous Wistar rats were obtained from Lagos State University College of Medicine Animal House. Female rats $240 \pm 10 \mathrm{~g}$ (mean \pm s.e.m.) were mated overnight with proven male breeders and the day on which spermatozoa 
were present in a vaginal smear was designated as the day of conception day 0 .Animal allocation to treatment groups was done by body weight randomization to ensure unbiased weight distribution among groups.

There were five animals per group and dosage for all groups except control was $950 \mathrm{mg} / \mathrm{kg}$ bwt (recommended therapeutic dose, DRUGSTORE.COM, 2004) via oral dosing syringe. Group 1: Control animals received distilled water, Group 2: Were administered RCO between gestation days (GD) 1-7, Group 3: Were administered RCO between GD 7-14, Group 4: Were administered RCO between GD 14-21, Group 5: Were administered RCO between GD 1-21.

Individual dams and offspring were housed in polycarbonate cages until weaning (PND 21), at which time animals were group-housed, up to 4 per cage, by sex and treatment.

Preparation of RCO: This was done as previously described (SALAMI and RAJI, 2014).

\subsection{Sample collection}

The Fl male offspring were sacrificed by cervical dislocation on postnatal day 90 . The testes and epididymis were carefully dissected out and weighed.

\subsection{Histological and histopathological procedures}

The testes and epididymis from all animals were fixed in $10 \%$ bouins fluid. They were processed routinely, sectioned and stained with haematoxylin and eosin and examined under the microscope.

\subsection{Histomorphometry}

The slides were examined under the Light microscope (10X) and the following measurements were taken; Seminiferous tubular diameter (STD), seminiferous luminal diameter (SLD) and epithelial height $(\mathrm{EH})$ of both peripheral and central seminiferous tubules were measured in the testes. Epididymal tubular diameter (ETD), epididymal luminal diameter (ELD) and epididymal epithelial height $(\mathrm{EEH})$ were measured in epididymis. For each parameter, ten measurements were made per section using a calibrated eye-piece micrometer (Leiz wizler ${ }^{\circledR}$, Germany). The means of the measurements of parameter in each section were recorded for each animal.

\subsection{Statistical analysis}

The results obtained in the present study were expressed as the mean \pm SEM. Using Prism Graph pad 5.01 version, Statistical analysis was applied to find significant difference between the values of control and treated groups with $\mathrm{p}<0.05$ taken as statistical significant.

\section{Results}

\subsection{Histopathology}

Histopathological examination of sections of the epididymis compared to the control showed that no visible lesions were noticed in Fl males from the treated groups with the exception of sparse epididymal luminal content seen in male offspring from GDl-7, GD 7-14 and GDl-21 (Figure 1). However, in Figure 2, moderate interstitial oedema was present in male offspring from GD1-7 and GD1-21. In addition, seminiferous tubular luminal content was reduced in Fl males from GD7-14 when compared to the control.

\subsection{Histomorphometry}

Seminiferous tubular diameter (STD) significantly $(\mathrm{p}<0.001)$ increased in Fl males from GD1-7, 7-14, 14-21 relative to control group; but no significant difference $(\mathrm{p}>0.05)$ between F1 males from control and GD 1-21 (Table 1). Seminiferous
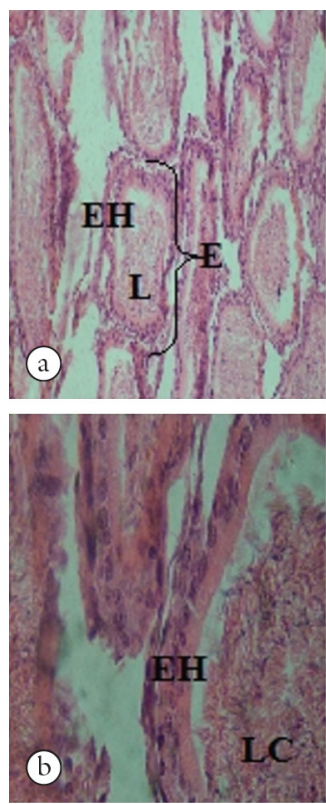
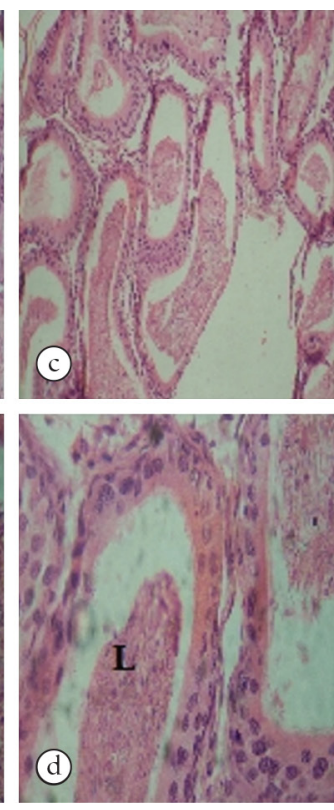
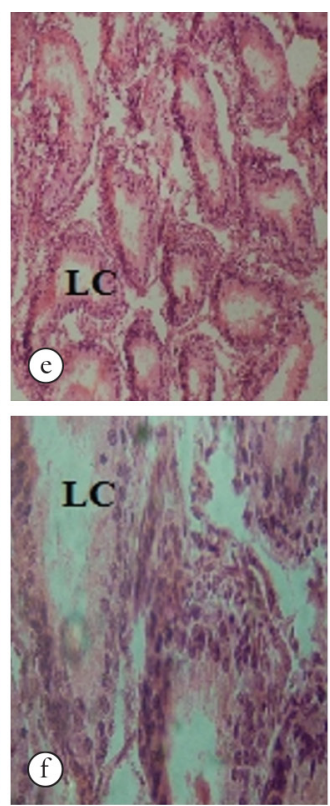
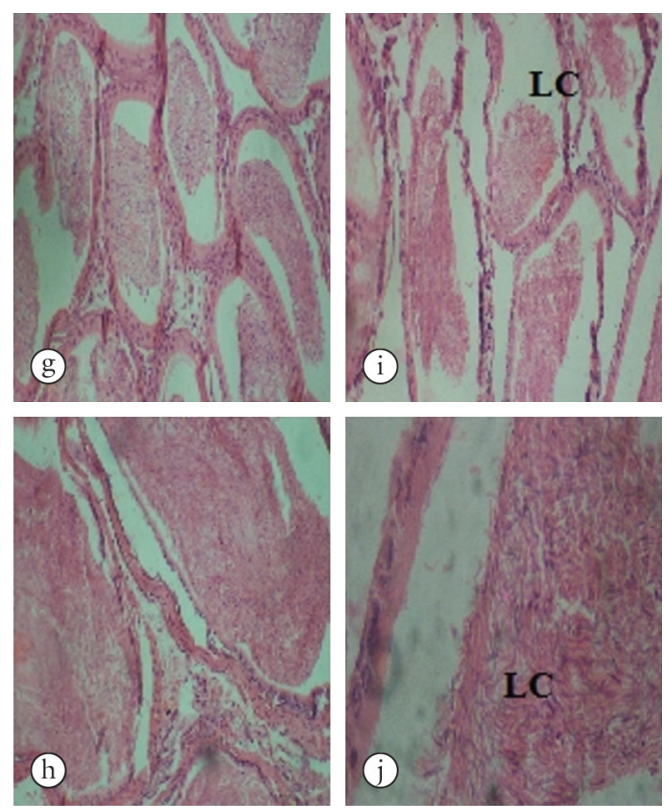

Figure 1. Photomicrograph of a section in the epididymis of rats. (a) Control: normal architecture of epididymis (E) with normal epithelial height (lining) (EH) and well filed lumen (L) (H\&E, x200); (b) Control: Normal epididymal architecture with normal epithelial height (lining) (EH) and well filed lumen (L) with numerous sperm cells, (H\&E, x400); (c) G 1-7: No visible lesion seen (H\&E, x200); (d) G 1-7: partially filled lumen (L), (H\&E, x400); (e) G 7-14 has a normal epididymal architecture but sparse luminal content (LC); (f) G 7-14: sparse luminal content (LC), (H\&E, x400); (g) 14-21: no visible lesion seen, (H\&E, x200); (h) G 14-21 no visible lesion seen; (i) G 1-21: has normal epididymal architecture but luminal content (LC) appear reduced), (H\&E, x200); (j) G1-21: reduced luminal content $(\mathrm{LC}),(\mathrm{H} \& \mathrm{E}, \mathrm{x} 400)$. 
tubular epithelial height $(\mathrm{SEH})$ significantly $(\mathrm{p}<0.001)$ decreased in Fl males from GD1-7,7-14 and 1-21 compared to the control. However, there was no significant difference between the SEH of Flmale from GD 14-21 and the control (Table 1). The seminiferous luminal diameter (SLD) however increased significantly $(\mathrm{p}<0.001)$ in Flmales from GDl-7, 7-14, 14-21 and 1-21 compared to the control.
Epididymal tubular diameter (ETD) significantly $(\mathrm{p}<0.01$ and $\mathrm{p}<0.05)$ increased in Fl males from GDl-7, 7-14, 14-21 relative to control group; but no significant difference ( $p>0.05)$ between control and GD 1-21 Fl males (Table 2). Epididymal tubular epithelial height $(\mathrm{EEH})$ significantly $(\mathrm{p}<0.001)$ increased in Fl males from GDl-7 and GD7-14 compared to the control group as shown in
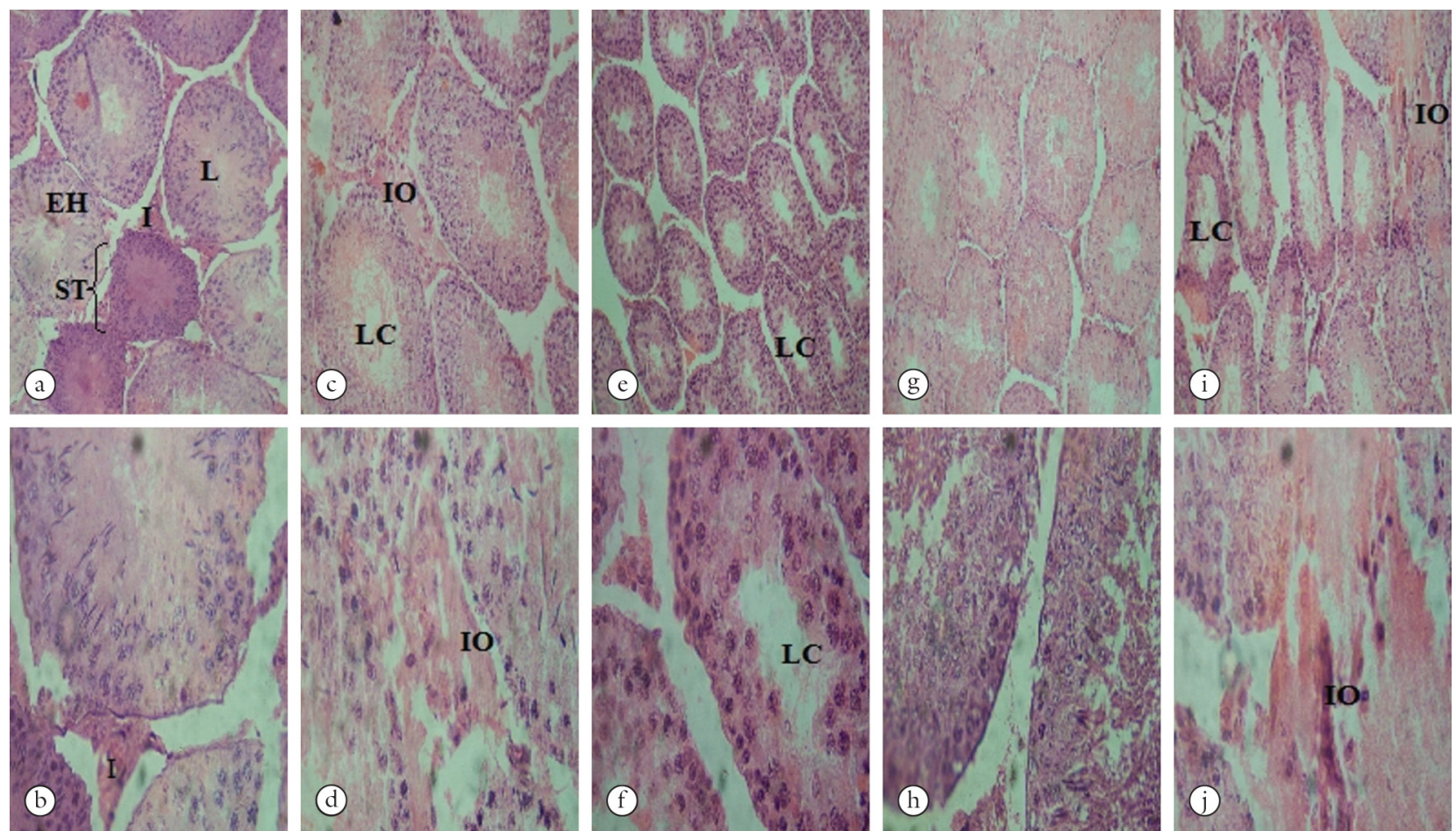

Figure 2. Photomicrographof section in the testis of rats. (a) control: normal architecture of testid with thicke epitheliakl (EH) of seminiferous tubule (ST), well filledlumen (L) with numerous spermatozoa and intact interstitium (I), (H\&E, x200); (b) Normal seminiferous tubule (ST), architecture with intact interstitium (I) (H\&E, x400); (c)1-7: sparse luminal content (LC) (H\&E, x200); (d) 1-7 There is very mild interstitial oedema (IO), (H\&E, x 400); (e) 7-14 has a normal seminiferous tubules (ST) architecture but sparse luminal content (LC); (f) 7-14 sparse luminal (LC), (H\&E, x400); (g) 14-21 no visible lesion seen (H\&E, x200); (h) no visible lesion seen; (i)1-21 reduced luminal content (LC) and mild interstitial oedema (IO), (H\&E x200); (j) l-2l mild interstitial oedema (IO) (H\&E, x400).

Table 1. Effects of maternal treatment with RCO at different gestation periods on testicular. Histomorphometry of F1 males.

\begin{tabular}{llcc}
\hline & STD $(\mu \mathrm{m})$ & SEH $(\mu \mathrm{m})$ & $\mathrm{SLD}(\mu \mathrm{m})$ \\
\hline Groups & & & $6.78 \pm 0.50$ \\
Control & $19.66 \pm 0.98$ & $16.30 \pm 0.92$ & $17.47 \pm 0.80^{* * *}$ \\
GD1-7 & $23.22 \pm 0.85^{* *}$ & $5.75 \pm 0.37 * * *$ & $16.55 \pm 0.47^{* * *}$ \\
GD7-14 & $24.04 \pm 0.61^{* * *}$ & $7.40 \pm 0.57 * * *$ & $8.360 .5^{*}$ \\
GD14-21 & $24.32 \pm 1.92^{*}$ & $15.96 \pm 1.53$ & $17.06 \pm 1.02^{* * *}$ \\
GD1-21 & $19.66 \pm 0.98$ & $2.67 \pm 0.19 * * *$ & \\
\hline
\end{tabular}

$\mathrm{Key}^{*}=\mathrm{p}<0,05 .{ }^{* *}=\mathrm{p}<0,01 .{ }^{* * *}=\mathrm{p}<0,001$. STD - seminiferous tubular diameter; SHA - seminiferous epithelia height; SLD - seminiferous luminal diameter; GD - Gestation days.

Table 2. Effects of maternal treatment with RCO at different gestation periods on epididymal. Histomorphometry of F1 males.

\begin{tabular}{lllc}
\hline & ETD $(\mu \mathrm{m})$ & EEH $(\mu \mathrm{m})$ & $\operatorname{ELD}(\mu \mathrm{m})$ \\
\hline Groups & & & $17.67 \pm 1.28$ \\
Control & $23.56 \pm 1.17$ & $2.60 \pm 0.24$ & $25.35 \pm 1.64^{* * *}$ \\
GD1-7 & $28.98 \pm 1.61^{* *}$ & $3.49 \pm 0.34^{*}$ & $15.14 \pm 0.67$ \\
GD7-14 & $11.32 \pm 0.72^{* *}$ & $4.18 \pm 0.21^{* * *}$ & $1754 \pm 1.00$ \\
GD14-21 & $20.48 \pm 1.04^{*}$ & $2.95 \pm 0.21$ & $19.93 \pm 1.53$ \\
GD1-21 & $22.81 \pm 1.55$ & $2.47 \pm 0.21$ & \\
\hline
\end{tabular}

Key ${ }^{*}=\mathrm{p}<0,05 .{ }^{* *}=\mathrm{p}<0,01 .{ }^{* * *}=\mathrm{p}<0,001$. ETD - epididymal tubular diameter; EEHA - epididymal epithelia height; ELD - epithelia luminal diameter; GD - Gestation. 
Table 2. However, there was no significant difference in the EEH of Fl males from GD 14-21 and 1-21 compared to the control. The epididymal luminal diameter (ELD) however increased significantly $(\mathrm{p}<0.001)$ only in Fl males from GDl-7 as shown in Table 2 .

\section{Discussion}

The use of histopathological evaluations, while evaluating animal tissue is of prominent role in male reproductive risk assessment. Organs that are often evaluated include the testes, epididymis, prostate, seminal vesicles, and pituitary. Histological evaluations are especially useful in providing a relatively sensitive indicator of damage; and with short-term dosing, providing information on target cells, extent of toxicity, and, indicating the potential for recovery. High quality information can be obtained on spermatogenesis from an adequately prepared testicular tissue (RUSSELL, ETTLIN, HIKIM et al., 1990; HESS and MOORE, 1993). The basic morphology of other male reproductive organs like the epididymis, and accessory sex glands have been described as well as the histopathologic alterations that may accompany certain disease states (FAWCETT, 1986; AKINLOYE, ABATAN, ALAKA et al., 2002).

The present study is quite germane as it is reporting on the histomorphometric changes in male Fl maternally exposed to therapeutic dose of RCO at different gestation periods. One of the major findings from our present work is the fact that RCO exposure at different gestation periods could impair negatively histomophormetry of the testes and epididymis of Fl males later at adulthood. Intrauterine programming can occur at any level within the affected physiological system and may involve structural and functional changes in genes, cells, tissues, and even whole organs. These changes may be isolated or widespread events with either discrete or cumulative effects on development depending on the nature and timing of the programming stimulus (MCMILLEN and ROBINSON, 2005 ). Induction of intrauterine growth retardation (IUGR) by maternal stress, hypoxia, glucocorticoid administration, dietary manipulation, or placental insufficiency have been reported to lead to postnatal abnormalities in cardiovascular, metabolic, and endocrine function in rats, guinea pigs, sheep, pigs, horses, and primates (FOWDEN, GIUSSANI and FORHEAD, 2005; MCMILLEN and ROBINSON, 2005). Studies by Matthews (2000), Bertram and Hanson (2002), Seckl (2004) in rats, guinea pigs, and sheep, have found out that fetal over-exposure to either endogenous or exogenous glucocorticoids leads to hypertension, glucose intolerance, and abnormalities in HPA function after birth. The specific postnatal effects of these treatments were found to not depend only on the gestational age at onset and the duration of exposure but also on the sex of the offspring.

In this study, apart from the Fl males from GDl4-21 that had no significant testicular lesions, histopathological observations showed that Fl males from other treated groups had varying degrees of testicular lesions that were moderate. In addition, significant increase was observed in the seminiferous tubular diameter of Fl males from GD1-7, 7-14 and 1-21 treated groups and in the epithelial epithelia heights of all treated groups. The pattern of cellular damage observed in this study is consistent with the effects of phoxim (ATEF, YOUSSEF, RAMADAN et al., 1995), oestradiol valerate (KÖHLER-SAMOUILIDIS, PAPIOANNOU,
KOTSAKI-KOVATSI et al., 1998) and Curcuma comosa extract (PIYACHATURAWAT, TIMINKUL, CHUNCHARUNEE et al., 1998 ) Calotropis procera extract (AKINLOYE, ABATAN, ALAKA et al., 2002) on the male reproductive organs. It is noteworthy to state that the itemized plant above share similar characteristics with RCO in being estrogenic in action. As the interstitium was observed to be mildly oedematous in GD1-7 and GD 1-21, the histological changes observed may be attributed to decreased production of testosterone known to be responsible for normal testicular architecture (EIK-NES, 1970). Testosterone levels were found to be reduced in RCO treated Fl male offspring in our previous study (SALAMI and RAJI, 2015). Despite the observed increase in the epididymal tubular diameter, epididymal luminal diameter, and epithelial height in some groups, the pseudo stratified features of the epididymal epithelium were relatively normal in all the treated groups. Although the effect of RCO on sperm volume was not examined in this study, our previous study showed that RCO impaired sperm volume, sperm count and morphology especially at GD 1-7, 7-14 and 1-21(SALAMI and RAJI, 2015).

\section{Conclusion}

This study indicates that maternal RCO exposure particularly during early gestation periods adversely affect testicular and epididymal histomorphometry with consequent impairment in fertility. These have been buttressed in our earlier studies where fertility capability was adversely affected in male offspring maternally exposed to RCO at different stages of gestation.

\section{References}

AKINLOYE, AK., ABATAN, MO., ALAKA, O. and OKE, B. O Histomorphometric and histopathological studies on the effect of Calotropis procera (giant milkweed) on the male reproductive organs of Wistar rats. African Journal of Biomedical Research, 2002, vol. 5, p. 57-61.

ATEF, M., YOUSSEF, SA., RAMADAN, A., NAWITO, MF., ELSAYED, MK. and ABD EL-RAHMAN, H. Influence of phoxim on testicular and seminal vesicle organs, testosterone and cholinesterase level and its tissue residues in male rats. Deutsche Tierarztliche Wochenschrift, 1995, vol. 102, n. 8, p. 301-305. PMid:8591759.

BERTRAM, CE. and HANSON MA. Prenatal programming of postnatal endocrine response by glucocorticoid. Reproduction, 2002, vol. 24, p. 459-467.

BOEL, ME., LEE, SJ., RIJKEN, MJ., PAW, MK., PIMANPANARAK, M., TAN, SO., SINGHASIVANON, P., NOSTEN, F. and MCGREADY, R. Castor oil for induction of labor: not harmful, not helpful. Obstetrical \& Gynecological Survey, 2010, vol. 65, n. 2, p. 77-78. http://dx.doi. org/10.1097/01.ogx.0000368137.31846.18.

COSMETIC INGREDIENT REVIEW EXPERT PANEL - CIREP. Final report on the safety assessment of Ricinus communis (Castor) seed oil, hydrogenated castor oil, ricinoleic acid, potassium ricinoleate, sodium ricinoleate, zink, and octyldodecyl ricinoleate. glyceryl ricinoleate, methyl ricinoleate, cetyl ricinoleate, ethyl ricinoleate, glycol ricinoleate, isopropyl ricinoleate. International Journal of Toxicology, 2007, vol. 26, supplement 3, p. 31-77. http://dx.doi. org/10.1080/10915810701663150. PMid:18080873.

DRUGSTORE.COM. Rite aid castor oil, stimulant laxative U.S.P. Package details: directions. Bellevue, 2004. Available from: <http:// www.drugstore.com>. Access in: 1 dec. 2004. 
EIK-NES, KB. Synethesis and secretion of andostetiedione and tesosterones. In EIK-NES, B. (Ed.). The androgens of the testis. 1970. p. 1-41.

FAWCETT, DW. Bloom and fawcett: a textbook of histology. Philadephia: W. B. Saunders, 1986.

FOWDEN, AL., GIUSSANI, DA. and FORHEAD, AJ. Endocrine and metabolic programming during intrauterine development. Early Human Development, 2005, vol. 81, n. 9, p. 723-734. http://dx.doi. org/10.1016/j.earlhumdev.2005.06.007. PMid:16085373.

GARRY, D., FIGUEROA, R., GUILLAUME, J. and CUCCO, V. Use of castor oil in pregnancies at term. Alternative Therapies in Health and Medicine, 2000, vol. 6, n. 1, p. 77-79. PMid:10631825.

HESS, RA. and MOORE, BJ. Histological methods for evaluation of the testis. In CHAPIN, RE. and HEINDEL, JJ. Methods in toxicology: male reproductive toxicology. San Diego: Academic Press, 1993. p. 52-85.

KÖHLER-SAMOUILIDIS G., PAPIOANNOU, N., KOTSAKIKOVATSI, VP. and VADARAKIS, A. The effect of oestradio valerate on the male reproductive organs and different semen parameters frats. Berliner und Münchener tierärztliche Wochenschrift, 1998, vol. 111 , no. 1, p. 1-5.

MATTHEWS, SG. Antenatal glucocorticoids and programme of the developing CNS. Pediatric Research, 2000, vol. 47, n. 3, p. 291300. http://dx.doi.org/10.1203/00006450-200003000-00003. PMid:10709726.

MCMILLEN, I. and ROBINSON, JS. Developmental origins of the metabolic syndrome: prediction, plasticity, and programming. Physiological Reviews, 2005, vol. 85, n. 2, p. 571-633. http://dx.doi. org/10.1152/physrev.00053.2003. PMid:15788706.

OKWUASABA, FK., OSUNKWO, UA., EKWENCHI, MM., EKPENYONG, KI., ONWUKEME, KE., OLAYINKA, AO., UGURU, MO. and DAS, SC. Anticonceptive and estrogenic effects of a seed extract of Ricinus communis var. minor. Journal of Ethnopharmacology, 1991, vol. 34, n. 2-3, p. 141-145. http://dx.doi.org/10.1016/03788741(91)90031-8. PMid:1795517.
PIYACHATURAWAT, P., TIMINKUL, A., CHUNCHARUNEE, A. and SUKSAMRARN, A. Growth suppressing effect of curcuma comosa extract on male reproductive organs in immature rats. Pharmacentical Biology, 1998, vol. 36, n. 1, p. 44-49. http://dx.doi.org/10.1076/ phbi.36.1.44.4618.

RUSSELL, LD., ETTLIN, R., HIKIM, APS. and CLEGG, ED. Histological and histopathological evaluation of the testis. Clearwater: Cache River Press, 1990.

SALAMI, SA. and RAJI, Y. Oral Ricinus communis oil exposure at different stages of pregnancy impaired hormonal, lipid profile and histopathology of reproductive organs in Wistar rats. Journal of Medicinal Plant Research, 2014, vol. 18, n. 44, p. 1289-1298.

SALAMI, SA. and RAJI, Y. Generational reproductive outcomes in Wistar rats maternally exposed to Ricinus communis oil at different stages of gestation. Journal of Developmental Origins of Health and Disease, 2015, vol. 6, n. 5, p. 443-453. http://dx.doi.org/10.1017/ S2040174415001245. PMid:26118402.

SAVABIEASFAHANI, M., KANNAN, K., ASTAPOVA, O., EVANS, NP. and PADMANABHAN, V. Developmental programming: differential effects of prenatal exposure to bisphenol-a or methoxychlor on reproductive function. Endocrinology, 2006, vol. 147, n. 12, p. 59565966. http://dx.doi.org/10.1210/en.2006-0805. PMid:16946013.

SECKL, JR. Prenatal glucocorticoids and long-term programming. European Journal of Endocrinology, 2004, vol. 151, supplement 3, p. U49-U62. http://dx.doi.org/10.1530/eje.0.151U049. PMid:15554887.

STEINGRUB, JS., LOPEZ, T., TERES, D. and STEINGART, R. Amniotic fluid embolism associated with castor oil ingestion. Critical Care Medicine, 1988, vol. 16, n. 6, p. 642-643. http://dx.doi. org/10.1097/00003246-198806000-00016. PMid:3371030.

Received June 4, 2015 Accepted November 23, 2015 